REGULAR ARTICLE

\title{
ECOLOGICAL CHARACTERISTICS OF THE DIFFERENT ECOSYSTEMS IN COASTAL AREAS OF THE ANDAMAN ISLANDS
}

\author{
E. Dilipan ${ }^{1}$, E.P. Nobi ${ }^{1,2}$ and T. Thangaradjou ${ }^{1,3}$ \\ ${ }^{1}$ Centre of Advanced Study in Marine Biology, Faculty of Marine Sciences, Annamalai University, \\ Parangipettai - 608 502, Tamilnadu, India \\ ${ }^{2}$ Ministry of Environment, Forest and Climate Change, Jor Bhag Road, New Delhi-110003, India \\ ${ }^{3}$ Science and Engineering Research Board, Department of Science and Technology, Government of India, \\ New Delhi 110070, India
}

\begin{abstract}
Coastal ecosystems are well known for their higher primary and secondary productivity and support of diverse floral and faunal communities. Especially coral reef and seagrasses create, as well as occupy, important niches in shallow water environments. Physico-chemical characteristics of the critical habitats (Mangrove, seagrass, dead coral bed and sandy beach) of Andaman Islands were studied. Physico-chemical parameters recorded in 18 stations showed distinct variations among different ecosystems, especially chemical parameters showed notable variations in all these ecosystems. Sediment characters showed significant variations: $\mathrm{pH}$ of the sediments varied between 8.1 and 8.6 in all the sampling locations and the electrical conductivity of the sediments varied between 2.1 and $4.1 \mathrm{dSm}-1$. Sediment nutrients varied widely: nitrogen (22-52 kg/acre), phosphorus (10-15 kg/acre) and potassium (55-73 kg/acre). Though the physico-chemical parameters showed distinct variations among different ecosystems, they are within the optimum range reported for the specific ecosystems prevailing in the area. In general, the nutrient level of water in the seagrass and mangroves was low when compared similar ecosystems of the mainland. It is important to note that, though the ambient water quality of these ecosystems is at the optimum level reported for the respective ecosystems, proper attention should be paid to maintain the subtle nature of the ecosystems of the islands, under the post-tsunamic geomorphological variations, increasing national and international tourism activity and the changing climatic conditions.
\end{abstract}

Keywords: Ecosystems, Mangrove, Seagrass, Salinity, Nutrients

\section{INTRODUCTION}

The Andaman and Nicobar Islands are rich in biodiversity and are protected by natural barriers by their geographical isolation from the mainland. Low population and non industrialization of these islands help maintain the island waters and coastal ecosystems in pristine condition. On the other hand, the pristine clear, non-polluted waters of the Andamans attracted different industries especially sea farming. Only limited research was carried out in Andaman group of islands about the natural environment and the physico-chemical properties prevailing in different ecosystems [1]. At the same time, sediments are a source of nutrients for seagrass growth [2]; replenishment of nutrients in the reef waters is due to the re-mineralization which takes place in the top layers of the sediments [3]; and changes in the sea level have negative impact on mangroves [4]. In case of Andaman Islands, change in geomorphology due to 2004 earthquake and tsunami caused serious impacts on water ways of mangroves of this region, either by dumping sediments by the giant tsunami waves and also by raising the land on the northern part of the islands over, due to tectonic activity and seawater usually raising upto $2.4 \mathrm{~m}$ above mean sea level was reaching the mangroves [5]. Similarly, coral reefs of this group of islands have also been exposed permanently at least during low tide along the northern part of the Andaman Islands for the above reasons.

Lean and Hinrichen [6] has reported that the seagrasses of the southeast Asian countries are under threat due to loss of mangroves, various coastal developments, urban expansion and tourism development. Increasing infrastructure developmental activities in many of the islands, as a post tsunami measure and its related transportation of construction materials, cause serious

\section{Received 12 September 2017; Accepted 29 December 2017 \\ *Corresponding Author \\ E. Dilipan}

1Centre of Advanced Study in Marine Biology, Faculty of Marine Sciences, Annamalai University, Parangipettai - 608502 , Tamilnadu, India

Email: gerberadilip@gmail.com

(T) This article is open access and licensed under the terms of the Creative Commons Attribution License (http://creativecommons.org/licenses/by/4.o/) which permits unrestricted, use, distribution and reproduction in any medium, or format for any purpose, even commercially provided the work is properly cited. Attribution - You must give appropriate credit, provide a link to the license, and indicate if changes were made. 
damage to the water quality of the coastal region. Under these conditions, background values on physico-chemical parameters for future comparison would be of paramount importance. Moreover, most of the islands taken for the present study are the sites recommended for prioritizing biodiversity conservation [7]. Therefore, considering the importance of biodiversity and the threats posed to these resources, it is high time to know the water quality of different environmental habitats, especially in the Andaman group of islands, which would definitely help to conserve and manage these resources appropriately.

\section{MATERIALS AND METHODS}

\section{Study area}

Andaman and Nicobar archipelago (latitude: 60450$130410 \mathrm{~N}$ and longitude: 920120-930570E) with over 572 islands lie $1200 \mathrm{~km}$ away from Indian eastern coast in the lap of the Bay of Bengal. Fringing and barrier reefs dominate the Andaman Islands forming a natural barrier to the wave energy from the Bay of Bengal [8]. Coral reefs form the dominant ecosystem creating habitats for seagrasses and mangroves in the lagoons and creeks protected by the reef [9]. The climate is typical of tropical islands of similar latitude, with a temperature range of 23$310 \mathrm{C}$ with irregular rainfall $(3000 \mathrm{~mm})$ usually dry during October to March and high humidity (70-80\%). For understanding the environmental characteristics in different ecosystems in the Andaman Islands, field survey was carried out in 18 marine locations (fig. 1) which falls in south, middle and north Andaman Islands during November to December, 2007. Respective dominant ecosystem also indicated in the map itself as follows mangrove (MG), seagrasses (SG), dead coral (DC) and sandy beach (SB).

\section{Ecological data sampling and analysis}

Temperatures (atmospheric and water) were recorded using LCD portable Digital Multi-Stem thermometer (MEXTECH Multi-Thermometer). Salinity measurement was done by refractometer (Atago, Japan). Water $\mathrm{pH}$ was determined using a $\mathrm{pH}$ pen ( $\mathrm{pH}$ tester 2, Oakton). Electrical conductivity and $\mathrm{pH}$ of the sediment samples were recorded using EC-TDS analyzer (CM 183, Elico Pvt. Ltd, India). DO was measured by following the Winkler's method described by Strickland and Parsons [10]. Concentrations of nitrate, nitrite, reactive silicate and inorganic phosphate were determined by standard method [10]. Particulate Organic Carbon (POC) was determined by wet ash method [11]. Sediment nutrients (nitrogen and phosphorus) were analysed in the Sugarcane Breeding Research Institute, Cuddalore by following the Kjeldahl method [12] and calorimetric method [13]. Potassium concentration was estimated following the methodology given by Guzman and Jimenez [14].

\section{RESULTS}

The air (27.5-32 oC) and surface water (26.2-29.9 oC) temperatures recorded the maximum at mangrove and seagrass ecosystems respectively while dead coral and sandy beach environs registered comparatively lower temperatures (fig. 2). In general, in all the habitats, surface water temperature was low and it followed the trend of air temperature. This indicates the influence of air temperature on the surface water temperature. Salinity fluctuated between $34-35 \%$ in the mangrove and dead coral environs, (34-36\%o) in seagrass and sandy beach areas and sandy beach recorded only $35 \%$ (fig. 3 ). Water $\mathrm{pH}$ ranged from 7.8-8.1 (fig. 4) in the study areas.

Dissolved oxygen (DO) varied from 3.8 to $5.33 \mathrm{ml} / \mathrm{l}$ (fig. 5). Higher DO $(5.33 \mathrm{ml} / \mathrm{l})$ was recorded in the mangrove ecosystem followed by that of the seagrasses while seagrass, dead coral and sandy beach habitats recorded low DO (3.8 ml/l). But, seagrass areas showed a wide range of DO (3.8-4.87 ml/l), as compared to all the other ecosystems.

In the water nutrients, seagrass (1.68-6.10 $\mu \mathrm{M})$ and mangrove (1.7-5.20 $\mu \mathrm{M})$ ecosystems registered a wide range of nitrate concentration when compared to dead coral (1.8-2.8 $\mu \mathrm{M})$ and sandy beach $(2.18 \mu \mathrm{M})$ (fig. 6a). Nitrite recorded a wide range of 0.39-0.95 $\mu \mathrm{M}$ in seagrass ecosystem while in all other ecosystems (mangrove 0.52$0.7 \mu \mathrm{M}$; dead coral 0.52-0.54 $\mu \mathrm{M}$; $0.53 \mu \mathrm{M}$ ) it fluctuated within a small range of $0.52-0.7 \mu \mathrm{M}$ (fig. 6b). Reactive silicate varied between 6.26 and $14.69 \mu \mathrm{M}$ and it was higher in sandy beach and dead coral areas when compared with seagrass and mangrove waters (fig. 6a). Inorganic phosphate (fig. 6b) ranged between 1.80 and $4.62 \mu \mathrm{M}$, with the unusually higher concentration in the mangrove waters while seagrass areas registered relatively low level among all the four ecosystems. Particulate organic carbon (POC) ranged from 1.38-6.41 $\mu \mathrm{g} \mathrm{Cl-1}$ with the maximum in the seagrass ecosystem followed by dead coral and sandy beach ecosystems. Mangroves registered relatively lower mean POC concentration (fig. 7).

Electrical conductivity of soil samples registered higher values $4.10(\mathrm{dSm}-1)$ in the seagrass ecosystem. The EC value was in the order of increase from mangrove, sandy beach, dead coral and seagrass areas (fig. 8). In general, the soil samples of all the ecosystems were alkaline in nature with a narrow range of $\mathrm{pH}$ (7.8-8.6) (fig. 4). Relatively, low soil $\mathrm{pH}$ was recorded in the mangrove ecosystem while all the other three ecosystems registered a little higher but almost similar mean soil $\mathrm{pH}$.

As for as soil nutrients are concerned (fig. 9), seagrass ecosystem recorded higher nitrogen $(22-52 \mathrm{~kg} /$ acre), followed by the mangrove (40-45 kg/acre), dead coral (28$34 \mathrm{~kg} / \mathrm{acre}$ ) and sandy beach (41 kg/acre). In case of phosphate it is in the order of seagrasses (11-13.5 kg/acre), followed sandy beach $(13.5 \mathrm{~kg} / \mathrm{acre})$, dead corals (10-12.5 $\mathrm{kg} / \mathrm{acre}$ ) and mangroves (10.2-11.5 kg/acre). Whereas, potassium concentration was recorded high in mangroves (58-73 kg/acre), followed by seagrasses ( $55-73 \mathrm{~kg} / \mathrm{acre})$, dead coral (59-70 kg/acre) and sandy beach $(68 \mathrm{~kg} / \mathrm{acre})$ ecosystems.

\section{DISCUSSION}

Physico-chemical parameters are the most important factors responsible for the regulation of physical activities of biological organisms. In nature, each species has its own optimal environmental requirements for their growth and development. Other than, the organisms can withstand a minimum and maximum range for a shorter period of time. Such environmental parameters, if exceed the minimum or maximum requirements or such conditions persist for a greater period, then the physiology and biochemistry of the organisms can be affected deleteriously and can lead to the death of the organisms. Hence, recording of such environmental conditions of specific ecosystems will be useful in managing the resources. Considering these facts, the present study was carried out at four different ecosystems such as dead coral, sandy 
beach, mangrove and seagrass ecosystems of the Andaman Islands. All these four ecosystems differ in floral and faunal composition and are largely governed by hydrographical and soil characteristics. Though the 18 stations representing the 4 ecosystems showed clear spatial variations among the different ecosystems, registered distinct ranges of hydrographical and soil characteristics.

Temperature, an important physical parameter, is capable of influencing the prevailing ecosystem characteristics. Surface water temperature is considered to be a critical parameter for coral reefs and seagrass ecosystems. Increase in surface water temperature is often reported with massive coral bleaching events [15] in several parts of the world and $25-29^{\circ} \mathrm{C}$ is considered to be the critical threshold temperature for coral reefs for optimum growth [16]. Similarly, intertidal seagrasses are tolerant to high seawater temperature $\left(40-45^{\circ} \mathrm{C}\right)$ but increased exposure to temperature and/or desiccation can both lead to the condition known as "burning" [17]. Comparing to these levels, in the present study, seawater temperature was comparatively lesser in the seagrass areas whereas, it was higher in coral reef areas. Such increased surface water temperatures might be the reason for the coral reef bleaching events which subsequently lead to the death of the corals, in addition to low tide exposure to sunlight. Surface water temperature clearly showed significant positive correlation with atmospheric temperature in seagrass areas $(\mathrm{r}=0.645 ; \mathrm{P}<0.05)$, while in all the other ecosystems, no such relationship was found. This indicates that more than the atmospheric temperature, other factors like tidal flushing and external water inputs are also playing a major role in governing the ecosystems functions.

Salinity is another important parameter capable of influencing the submerged aquatic organisms. Salinity registered a significant positive relationship with atmospheric $(\mathrm{r}=0.769 ; \mathrm{P}<0.01)$ and surface water temperature $(\mathrm{r}=0.696 ; \mathrm{P}<0.05)$, in the seagrass ecosystem. In the case of mangrove ecosystem, significant negative relationship $(\mathrm{r}=-0.997 ; \mathrm{P}<0.01)$ was obtained between surface water temperature and salinity, revealing the fact that more than the temperature, other features like freshwater input might alter salinity levels. However, no such relationship was found in the case of dead coral and sandy beach areas. A salinity regime of around $35 \%$ has been prescribed as the best for good coral growth, whereas mangroves and seagrasses are capable of tolerating a wide range of salinities. Present results have indicated that there is a narrow range of salinity (34-36\%o) in the ecosystems studied, indicating optimal salinity ranges reported for all the ecosystems. Sridhar et al. [18] reported that 28-36\%o salinity range from the seagrass and coral reef areas of Palk Bay region while, 34-44 \%o of salinity was reported from the mangroves of the Gulf of Kuchch [19]. Water pH remained alkaline at all the sampling stations with a narrow range (7.8-8.1) which is quite normal for all the coastal ecosystems.

Dissolved oxygen, a critical parameter for the distribution of aquatic animals, has been recorded with comparatively lower values ( 3.8 and 5.33 mll-1) at the study areas, which is relatively low when compared to the DO levels reported from similar ecosystems of the other parts of India. A DO range of 9.2-13.0 mgl-1 in the seagrass meadows of the Kavarathi island [20], 3.15-6.68 mll-1 from coral reef and seagrass environment of the Palk Bay have been reported earlier [17]. There was also no significant statistical relationship between any of the tested parameters with DO. Despite the lower animal migration and metabolisms existing in the dead coral reef beds and sandy beaches, the DO input through phytoplankton, seaweeds and seagrasses are also less in these ecosystems when compared to the seagrass and mangrove habitats which leads to the overall increase in DO level in these ecosystems.

Mangroves are always known for holding higher nutrient levels while seagrasses can tolerate the level of eutrophication than coral reefs which are basically oligotrophic in nature [21]. Though the seagrass ecosystems are capable of withstanding higher nutrient levels when compared to coral reef ecosystems, they may also get affected by persistent higher nutrient levels for longer periods [18]. It is worth mentioning that, seagrasses and corals in different parts of the world are disappearing fast due to nutrient enrichment [22, 23].

Oxidation of ammonia by recycling of nitrogen and bacterial decomposition of planktonic detritus [24] and also denitrification, air-sea interactions [25] are all contributing to $\mathrm{NO} 2$ in the marine environment. In the present study, nitrite ranged from 0.39 to $0.95 \mu \mathrm{M}$, in the sampling stations. Higher concentration of nitrite could be attributed to the variation in phytoplankton excretion, oxidation of ammonia and reduction of nitrate besides others. The nitrate range (1.68-6.1 $\mu \mathrm{M})$ reported in the present study was relatively low as compared to that of mangrove and seagrass ecosystems. Nitrate is the nutrient which commonly determines the plant biomass in the aquatic ecosystems.

Similarly, phosphate ranged between 1.8 to $4.62 \mu \mathrm{M}$, and this was low as compared to other areas. Sometimes, increased salinity of the range reported in the present study also capable of reducing the availability of nutrients [26]. This is evident from the significant negative relationship obtained between salinity and nitrite ( $\mathrm{r}=-$ $0.984 ; \mathrm{P}<0.05)$ and nitrate $(\mathrm{r}=-0.994 ; \mathrm{P}<0.05)$ in the mangrove ecosystem. For the seagrass ecosystems no such relationship was obtained and it is important to note that the seagrass ecosystem is known for their low nitrogen content [27-29] and phosphorus availability [30-32]. The sampling sites are also away from freshwater reaches and the possibility of any external nitrogen input to the coast is very minimum unless through land runoff during rainy seasons. On the other hand, world's most seagrass losses are associated with persistent increase of nutrient concentrations largely influenced by the external sources [22]. Similarly, corals are very sensitive to nutrients especially nitrogen and phosphorus. Generally, coral reef environment shows low phosphate concentration [33] as the increase in phosphate levels would suppress the calcification of corals, thereby affecting their growth. There were reports on existence of live corals in these parts earlier and they gradually degraded due to the multiple factors like increase in SST, nutrients, bleaching events besides the physical damages etc.

In the case of the mangrove ecosystem, presently reported range of nitrate levels was very much low $(1.7-5.20 \mu \mathrm{M})$ when compared to the estuarine mangroves (3.6-27.6 $\mu \mathrm{M})$ of Ashtamudi estuary [34] and riverine mangroves (18-46 $\mu \mathrm{g}$ l-1) of Pitchavaram [35]. Usually the fringe mangroves, flushed by the open ocean waters alone, would have only limited nutrient levels as that of the present study. 
Though reactive silicate is not a limiting nutrient in any of these ecosystems, comparatively higher range of silicate concentration was registered in sandy beach areas (11.2412.30 $\mu \mathrm{M})$ and lower ranges, in the mangrove habitats (6.26-10.25 $\mu \mathrm{M})$. The higher silicate concentration in the habitat, might be due to the mixing of silica materials by the higher wave action and water flow from the coastal environment. However, the increased silicate concentration with possible increase in temperature will have independent effects and potential for synergistically enhancing the development of micro and macro-algal blooms in coastal ecosystems [36], which would cause deleterious effects on coral and seagrass ecosystems.

POC was recorded maximum in the seagrass stations with a range of $1.38-6.41 \mu \mathrm{gCl}-1$, followed by dead coral and mangrove ecosystems. The death and decay of seagrass biomass might be the reason for the increased POC level in seagrass habitats. Similarly, seaweeds growing in the coral reef areas are capable of increasing the POC level in the region [18]. Decomposition and mineralization of plant biomass may also contribute to the increased nutrient load in the ecosystem as evidenced by the significant positive correlation between POC and nitrite $(\mathrm{r}=0.668 ; \mathrm{P}<0.05)$ and inorganic phosphate $(\mathrm{r}=0.668 ; \mathrm{P}<0.05)$ in dead coral area and inorganic phosphate $(\mathrm{r}=0.682 ; \mathrm{P}<0.05)$ in the seagrass area. Though the mangrove ecosystems are known for their increased POC levels, the biomass produced and defoliated by the fringe mangroves of the Andaman Islands might have been transported by the waves and tides to other parts of the sea by the tidal flashes. Though this might applicable to the other ecosystems the leaf biomass contributed by seagrasses and seaweeds in these ecosystems was comparatively higher than the mangrove ecosystem.

Sediment EC was in the decreasing order of seagrass, sandy beach, dead coral and mangrove ecosystems. Increased sand composition in the soil composition would favour the increased electrical conductivity. Because of this reason, the mangrove ecosystem with less sand and more silt and clay content registered lesser EC. Alkaline conditions prevailing in the seagrass sediment environment might have led to the higher EC throwing light on the role of sediment metal ions in effecting EC [9]. Moreover, surface soil of the seagrass ecosystem was comparatively more oxygenated than the other three ecosystems which in turn decrease the redox potential of the ecosystem while the mangroves are anoxic in nature [37].

As for as the soil nutrients are concerned, comparatively lesser nitrogen and increased phosphorus contents were recorded in the seagrass area, than that of the mangroves. This is in good agreement to the findings of Touchette and Burkholder [38] who reported $\mathrm{N}$ limitation in temperate seagrass areas, on the terrigenous or sandy sediments and P-limitation in the tropical environment on carbonate sediments. Increased flushing of tidal water could replenish the nutrients of mangrove soils, as silt and clay soils are capable of adsorbing more nutrients.

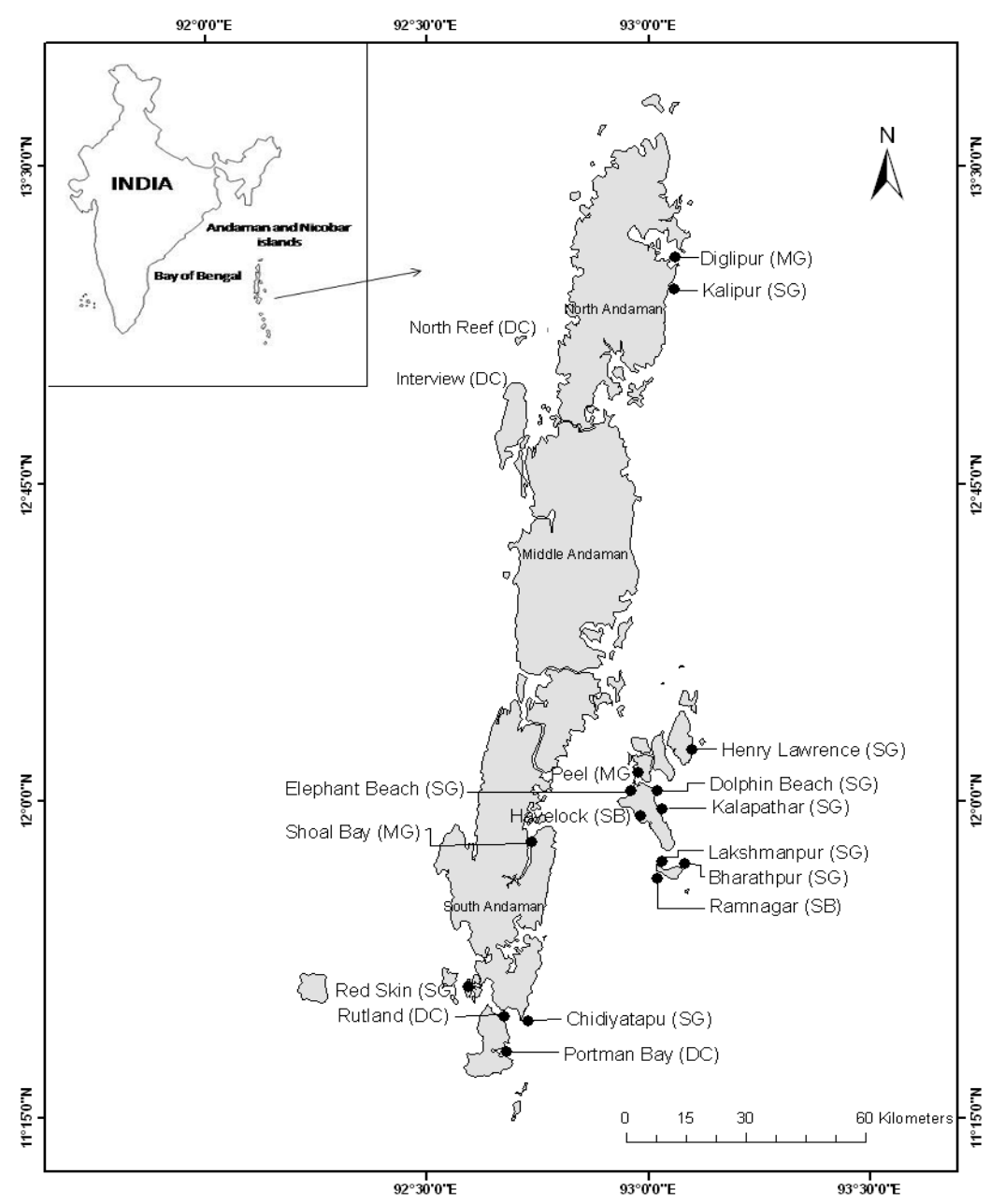

Fig. 1: Map showing the sampling locations. 
J. Exp. Sci. 2017, 8: 21-29

http://updatepublishing.com/journal/index.php/jes

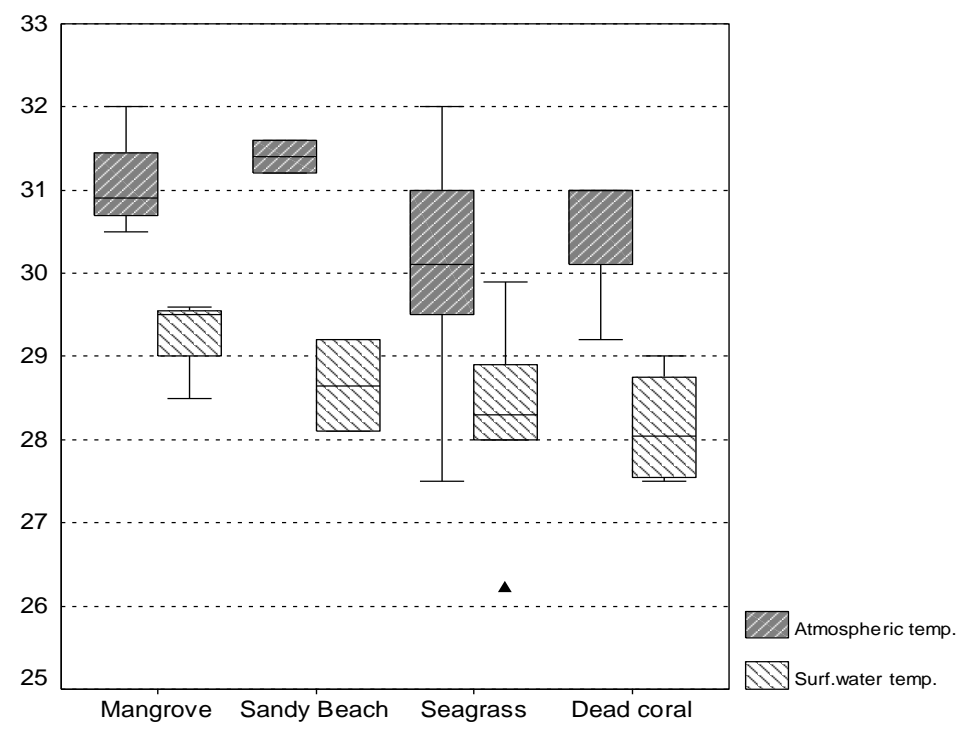

Fig. 2: Atmospheric and Surface water temperature in different ecosystems in the Study area.

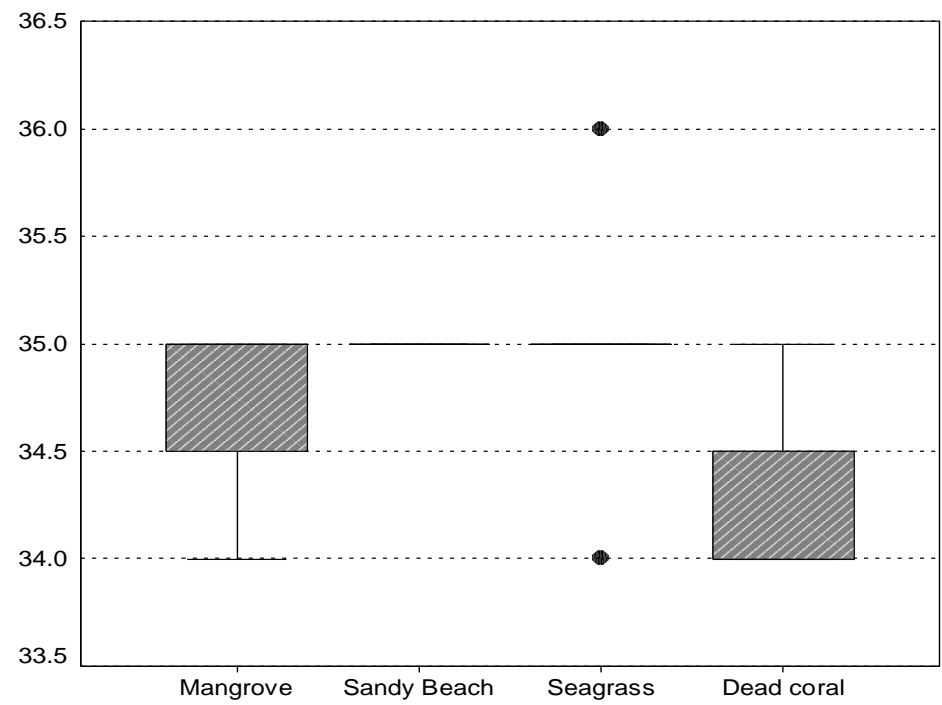

Fig. 3: Salinity in different ecosystems in the Study area.

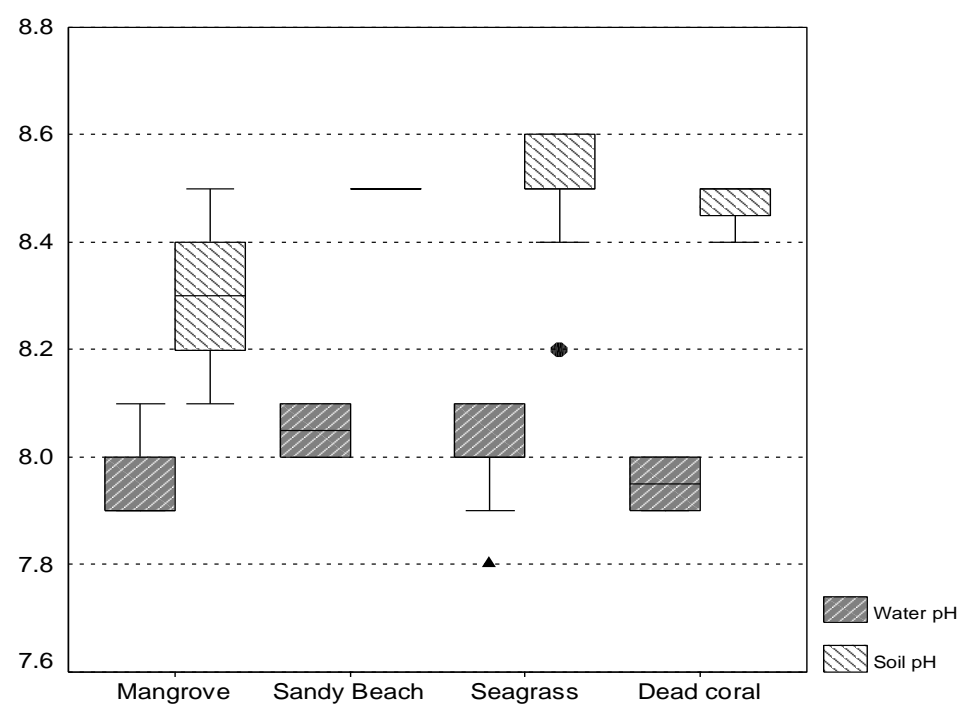

Fig. 4: Hydrogen ion concentration (pH) in different ecosystems in the Study area. 
E. Dilipan et al.

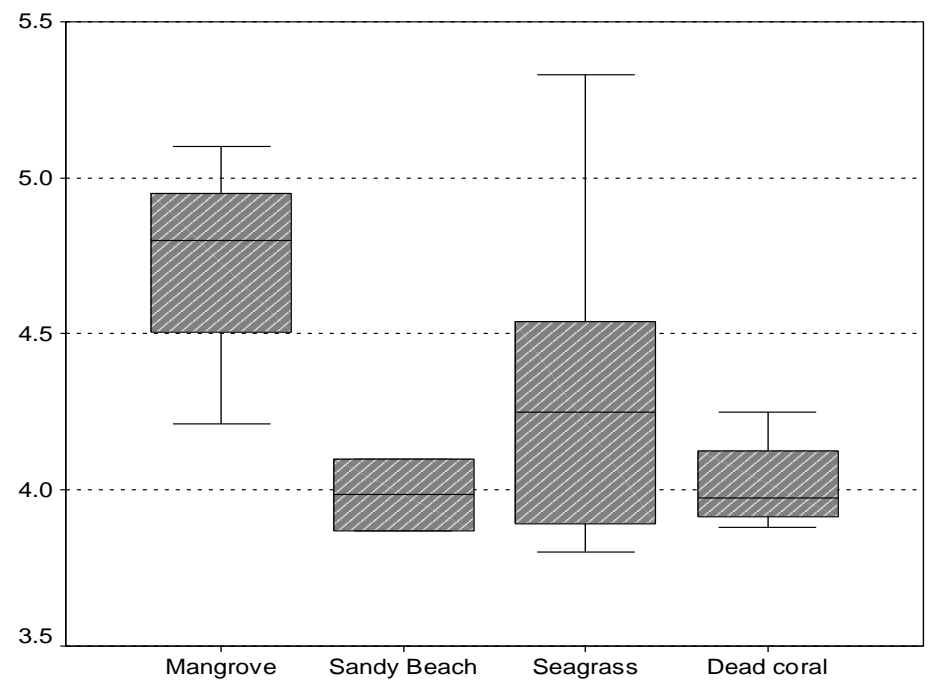

Fig. 5: Dissolved oxygen concentration (DO) in different ecosystems in the Study area.

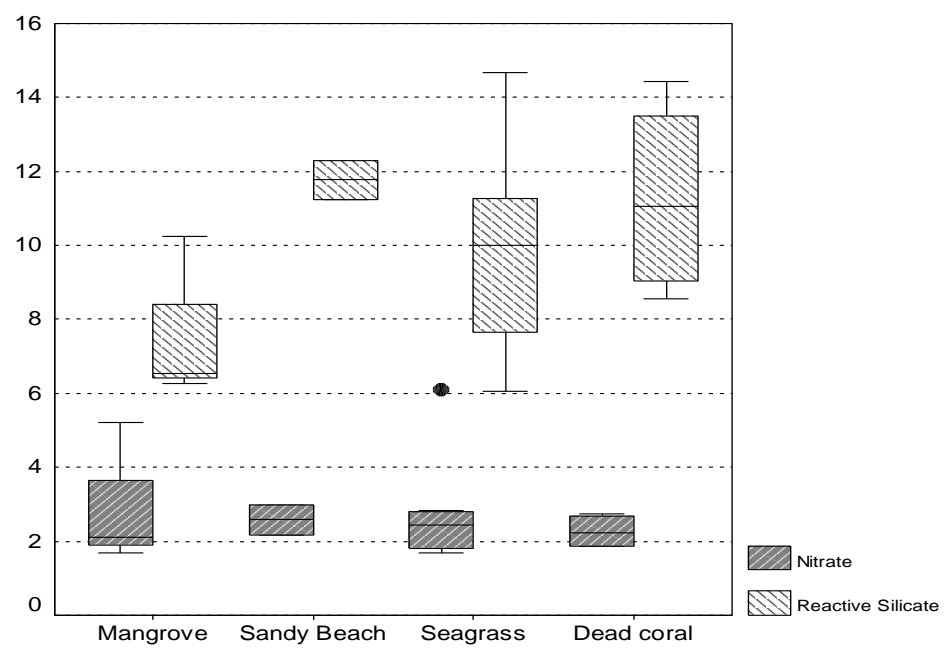

Fig. 6a: Concentration of water nutrients (Nitrate and Reactive Silicate) in different ecosystems in the Study area.

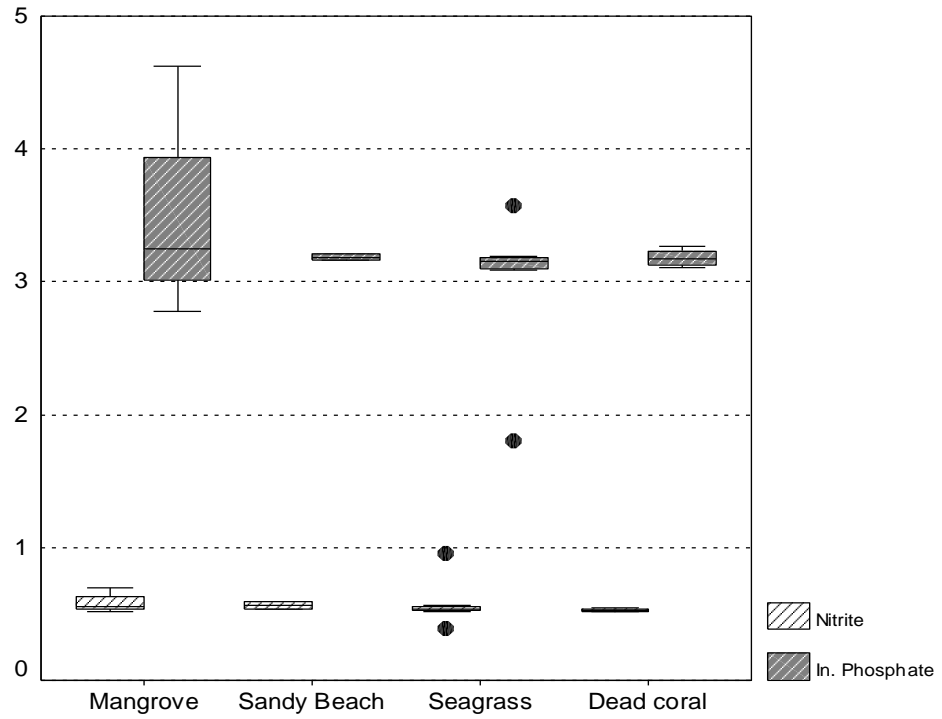

Fig. 6b: Concentration of water nutrients (Nitrite and Inorganic Phosphate) in different ecosystems in the Study area. 


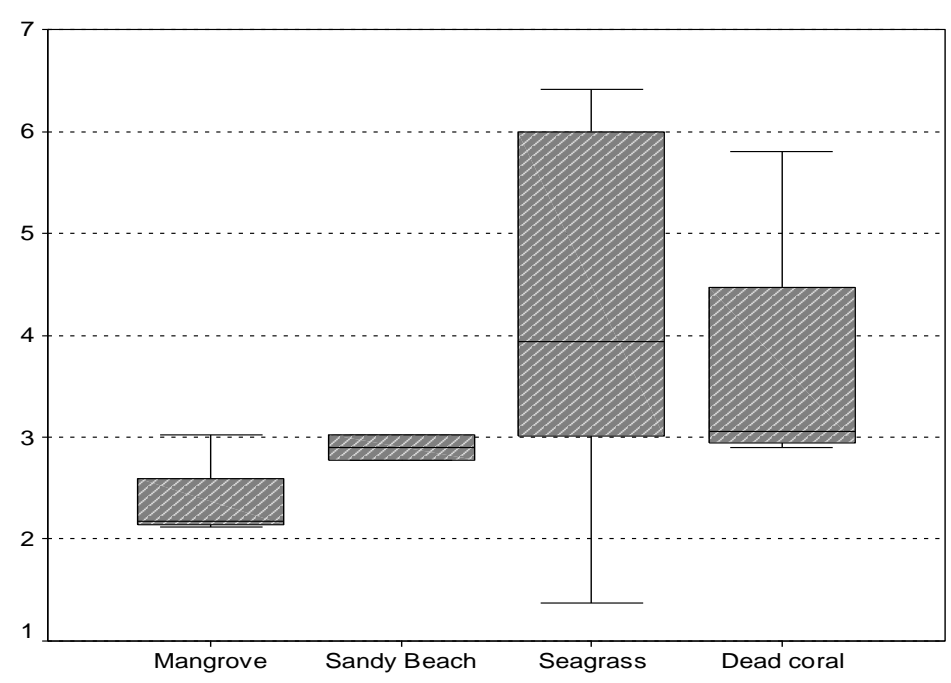

Fig. 7: Concentration of Particulate Organic Carbon (POC) in different ecosystems in the Study area.

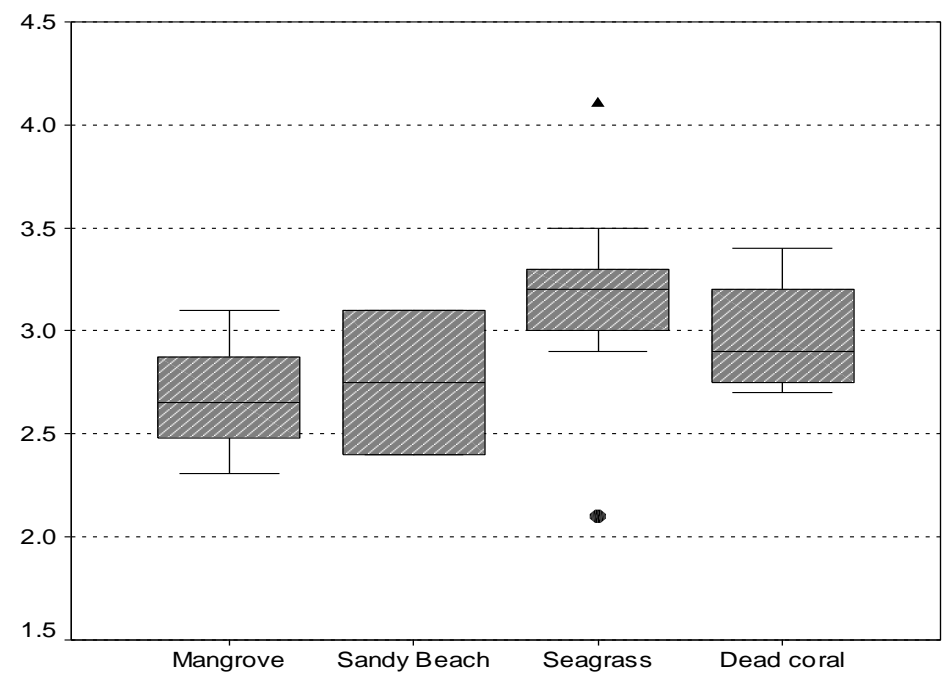

Fig. 8: Electrical conductivity of the sediments (EC) in different ecosystems in the Study area.

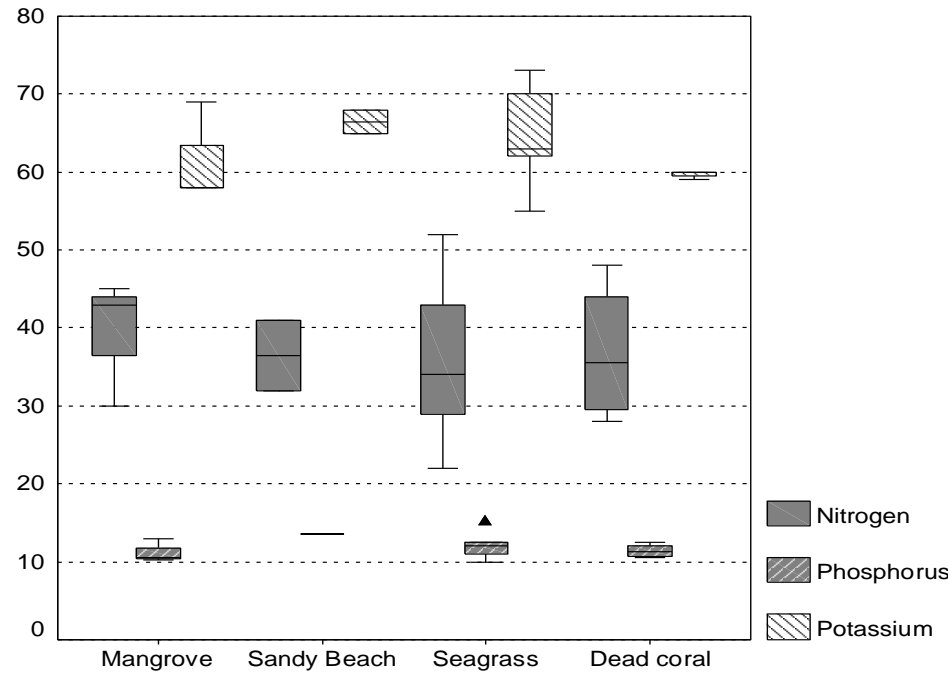

Fig. 9: Concentration of sediment nutrients in different ecosystems in the Study area.

(rectangle box- range of values, dark line inside the box-median,

$\Delta$-Extreme values,

- Outlying values). 


\section{CONCLUSION}

To conclude, values of the physico-chemical properties of the different ecosystems of the Andaman Islands are well within the limits reported for these ecosystems. However, nutrient levels of seagrass ecosystem are low when compared to those of the similar ecosystems of the mainland. Occurrence of coral reefs and seagrasses in the same area might be one of the reasons for having the lower nutrient level in this part of Bay of Bengal. Continuing developmental activities, increasing population, tourism etc. would definitely make impacts on the pristine nature of these ecosystems and increase the nutrient levels. This makes the system into more complex especially when all these habitats are existing at close ranges. These critical habitats are the main attractions for tourism and also the major residential and developmental areas are closer to these ecosystems. Such attraction would result in increased anthropogenic pressure in future also. Hence, these critical habitats are to be monitored continuously at regular intervals for checking any untoward environmental changes, with particular reference to the prevailing water quality parameters.

\section{ACKNOWLEDGEMENT}

Authors express their sincere gratitude to Director and Dean, Faculty of Marine Sciences and the authorities of the Annamalai University for facilities. Ministry of Environment and Forests, Government of India for financial support and the Department of Environment and Forests, Andaman and Nicobar Islands are gratefully acknowledged.

\section{REFERENCES}

1. Long LWJ, Mellors JE, Coles RG, Seagrasses between Cape York and Hervey Bay, Queensland, Australia. Austr J Mar Fresh Res. 1993;44:19-33.

2. Udy JW, Dennison WC, Estimating nutrient availability in seagrass sediments, In: Kuo J, Phillips RC, Walker DI, Kirkman H, editors. Seagrass Biology: Proceedings of an International Workshop. Rottnest Island Western Australia; 1996. p. 163-172.

3. Crossland CJ, Dissolved nutrients in coral reef waters. In: Barnes, DJ, editor. Perspectives on Coral Reefs. Brian Clouston/AIMS, Canberra; 1983. p. 56-68.

4. Cohen MCL, Lara RJ, Temporal changes of mangrove vegetation boundaries in Amazonia: application of GIS and remote sensing techniques. Wetland Ecol Manage. 2003;11:223-231.

5. Dam Roy S, Krishnan P, Mangrove stands of Andaman vis-a-vis tsunami. Curr Sci. 2005;89 18001804.

6. Lean G, Hinrichen D, WWF Atlas of the Environment. Oxford: Helicon Publishing. 1992. pp. 192.

7. Singh S, Sastry ARK, Mehta R, Uppal V, Setting biodiversity conservation priorities for India. (WWF, India) 2000. pp.707

8. Ramesh R, Arun Kumar R, Inamdar AB, Mohan PM, Prithviraj M, Ramachandran S, Purvaja R, Chingkhei K, Dolendro T, Venkataraman G, Khire MV, Gedam SS, Rao YS, Adinarayana J, Nagarajan R, Tsunami characterization and mapping in Andaman and Nicobar Islands, In: Rajamanikam GV, editor. 26th December 2004 Tsunami Causes, Effects Remedial Measures, Pre and Post Tsunami Disaster Management, a Geoscientific Perspective, New Academic Publisher, New Delhi; 2006. p. 150-174.
9. Nobi EP, Dilipan E, Thangaradjou T, Sivakumar K, Kannan L, Geochemical and geo-statistical assessment of heavy metal concentration in the sediments of different coastal ecosystems of Andaman Islands India. Estuar Coast Shelf S. 2010;87:253-264.

10. Strickland J, Parsons T, A Practical Handbook of Seawater Analysis. Bulletin 167 (2nd ed.), Fisheries Research Board Canada, Ottawa, Ont., Canada; 1972. pp. 310

11. Parsons TR, Takahashi, M, Hargrave B, Biological Oceanographic Processes. Pergamon Press, Oxford; 1984 .

12. Subbiah BV, Asija GL, A rapid procedure for the estimation of available $\mathrm{N}$ in the soils. Curr Sci. 1956;25:259-260.

13. Olsen SR, Cole CV, Watanabe FS Dean LA, Estimation of available phosphorus in soils by extraction with sodium bicarbonate. US Dept Agric Circ. 1954;939:119.

14. Guzman HM, Jimenez CE, Contamination of coral reefs by heavy metals along the Caribbean coast of Central America (Costa Rica and Panama). Mar Pollut Bull. 1992;24:554-561.

15. Sarkar SK, Banerjee K, Coral bleaching-problems and remedies. J Indian Ocean Stud. 2004;12:487-495.

16. Guilcher A, Coral reef geomorphology. John Wiley and Sons, New York: 1988.

17. Mckenzie L, Burning seagrass, Seagrass watch. 2010;40:2-3.

18. Sridhar R, Thangaradjou T, Kannan L, Comparative investigation on physico-chemical properties of the coral reef and seagrass ecosystems of the Palk Bay. Indian J mar Sci. 2008;37:207-213.

19. Saravanakumar A, Rajkumar M, Serebiah JS, Thivakaran GA, Seasonal variations in physicochemical characteristics of water, sediment and soil texture in arid zone mangroves of Kachchh-Gujarat. J Environ Biol. 2008;29:725-732.

20. Jagtap TG, Structure of major seagrass beds from three coral reef atolls of Lakshadweep, Arabian Sea, India. Aquat Bot. 1998;60:397-408.

21. Ogden John C. Coral reefs, seagrass beds and mangroves: Their interaction in the coastal zones of the Caribbean. In: Ogden John C, Elizabeth H Gladfelter, editors. Report of a Workshop, held at West Indies Laboratory, St. Croix, U. S. Virgin Islands May, 1982. UNESCO reports in marine science; 1983. p. 23-133.

22. Abal EG, Dennison WC, Seagrass depth range and water quality in southern Moreton Bay, Queensland, Australia. Mar Fresh Res. 1996;47:763-771.

23. Lapointe BE, Barile PJ, Yentsch CS, Littler MM, Littler DS, Kakuk B, The relative importance of nutrient enrichment and herbivory on macroalgal communities near Norman's Pond Cay, Exumas Cays, Bahamas: a "natural" enrichment experiment. J Exp Mar Biol Ecol. 2004;298:275-301.

24. Govindasamy C, Kannan L, Azariah J, Seasonal variation in physico-chemical properties and primary production in the coastal water biotopes of Coromandel coast, India. J Environ Biol. 2000;21:1-7.

25. Mathew L, Pillai VN, Chemical characteristics of the waters around Andaman during late winter. Proc. of First Workshop Scient. Resul. FORV. Sagar Sampada, 1990

26. Kathiresan K, Rajendran N, Thangadurai G, Studies on root growth in seedlings in intertidal area of Vellar estuary southeast coast of India. Indian $\mathrm{J}$ mar Sci. 1996;25:249-243. 
27. Kenworthy WJ, Fonseca MS, The use of fertilizer to enhance growth of transplanted seagrasses Zostera marina L. and Halodule wrightii Aschers. J Exp Mar Biol Ecol. 1992;163:141-161.

28. McGlathery KJ, Howarth RW, Marino R, Nutrient limitation of the macroalga Penicillus capitatus associated with subtropical seagrass meadows in Bermuda. Estuaries. 1992;15:18-25.

29. Lee KS, Dunton KH, Effects of nitrogen enrichment on biomass allocation, growth and leaf morphology of the seagrass Thalassia testudinum. Mar Ecol Prog Ser. 2000;196:39-48.

30. Perez M, Duarte CM, Romero J, Sand JK, Alcoverro T, Growth plasticity in Cymodocea nodosa stands: The importance of nutrient supply. Aquat Bot. 1994;47:249-264.

31. Fourqurean JW, Cai Yong, Arsenic and phosphorus in seagrass leaves from the Gulf of Mexico. Aquat. Bot. 2001;71:247-258.

32. Gras AF, Koch MS, Madden CJ, Phosphorus uptake kinetics of a dominant tropical seagrass Thalassia testudinum. Aquat Bot. 2003;76:299-315.
33. Kinsey DW, Davies PJ, Effects of elevated nitrogen and phosphrous on coral reef growth. Limnol Oceanogr. 1979;24:935-940.

34. Jennerjahn TC, Soman K, Ittekkot V, Nordhaus I, Sooraj S, Priya RS, Lahajnar N, Effect of land use on the biogeochemistry of dissolved nutrients and suspended and sedimentary organic matter in the tropical Kallada river and Ashtamudi estuary, Kerala, India. Biogeochem. 2008;90:29-47.

35. Perumal P, Heterogeneity of coastal ecosystems with special reference to mangroves. $\mathrm{Ph}$. $\mathrm{D}$. thesis Annamalai University, India. 1989

36. Kotze HK, Worm B, Complex interactions of climatic and ecological controls on macroalgal recruitment. Limnol Oceanogr. 2002;47:1734-1741.

37. Oxmann JF, Schwendenmann L, Lara RJ, Interactions among phosphorus, $\mathrm{pH}$ and $\mathrm{Eh}$ in reforested mangroves, Vietnam: a three dimensional spatial analysis. Biogeochem. 2009;96:73-85.

38. Touchette BW, Burkholder JM, Review of nitrogen and phosphorus metabolism in seagrasses. J Exp Mar Biol Ecol. 2000;250:133-167. 